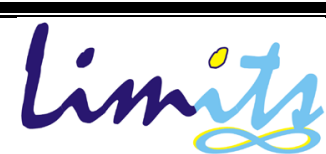

Limits: Journal of Mathematics and Its Applications

E-ISSN: 2579-8936

P-ISSN: 1829-605X

Vol. 18, No. 2, Nopember 2021, 95-107

DOI: http://dx.doi.org/10.12962/limits.v18i2.6170

\title{
Simulasi Numerik Persamaan Gelombang Air Dangkal 1D dengan Topografi Tidak Datar Menggunakan Metode Beda Hingga
}

\author{
Ririn Setiyowati ${ }^{1}$, Venna Ade Riestiana ${ }^{2}$ \\ 1,2Universitas Sebelas Maret; Jl.Ir. Sutami No.36 A, Puncangsawit, Jebres, Surakarta \\ 1,2Program Studi Matematika FMIPA UNS Surakarta \\ e-mail: ririnsetiyowati@staff.uns.ac.id,vennaaderiestiana.av@gmail.com
}

Diajukan: 28 Nopember 2019, Diperbaiki: 22 April 2021, Diterima: 19 Mei 2021

\begin{abstract}
Abstrak
Tsunami merupakan salah satu contoh gelombang panjang yang dapat dimodelkan secara matematis menggunakan persamaan gelombang air dangkal. Persamaan gelombang air dangkal dikonstruksi berdasarkan hukum konservasi massa dan momentum. Persamaan gelombang air dangkal 1D terdiri dari variabel ruang $x$ dan variabel waktu $t$. Metode beda hingga secara umum dapat digunakan untuk menentukan solusi numerik dari persamaan gelombang air dangkal nonlinear. Pada metode beda hingga terdapat beberapa skema salah satunya adalah skema Lax-Friedrichs. Dalam penelitian ini dilakukan kontruksi ulang persamaan gelombang air dangkal 1D dengan topografi tidak datar. Kemudian ditentukan solusi numerik dari persamaan gelombang air dangkal 1D menggunakan metode beda hingga skema Lax-Friedrichs. Simulasi numerik dilakukan dengan tujuan untuk mengetahui hubungan antara nilai awal amplitudo gelombang dan fungsi topografi terhadap tinggi gelombang tsunami yang dihasilkan. Hasil simulasi menunjukkan bahwa semakin besar amplitudo gelombang awal dan semakin curam fungsi topografi yang diberikan maka semakin besar tinggi gelombang yang dihasilkan waktu yang dibutuhkan gelombang untuk sampai ke daratan semakin singkat, dan jangkauan gelombang masuk ke daratan semakin jauh.
\end{abstract}

Kata Kunci: persamaan gelombang air dangkal, topografi, metode beda hingga, Lax-Friedrichs

\begin{abstract}
Tsunami is an example of long waves that can be mathematically modeled using shallow water wave equations. Shallow water wave equation is constructed based on the conservation law of mass and momentum. The $1 D$ shallow water wave equation consists of the space variable $x$ and the time variable $t$. Finite difference method can be used generally to determine the numerical solution of a nonlinear shallow water wave equation. Finite difference method has several schemes, one of them is LaxFriedrichs scheme. In this paper, we reconstruct the $1 D$ shallow water wave equation with non-flat topography. Then, we determine numerical solution using finite different method : Lax-Friedrichs scheme. Numerical simulations are carried out in order to determine the relationship between the initial value of the wave amplitude and the topographical function of the resulting tsunami wave height. The simulation results show that the greater the initial wave amplitude and the steeper the topographic function given, the greater the resulting wave height, the shorter the time it takes for the waves to reach the land, and the farther the reach of the incoming waves inland.
\end{abstract}

Keywords: Tsunami, shallow water wave equations, topography, finite difference method, Lax-Friedrichs 


\section{Pendahuluan}

Tsunami adalah gelombang berurutan yang memiliki amplitudo gelombang yang sangat besar. Menurut Synolakis [1], gelombang tsunami merupakan salah satu bentuk gelombang panjang. Perambatan gelombang panjang dapat dimodelkan secara matematis menggunakan persamaan gelombang air dangkal. Flouri et al.[2] menyebutkan bahwa gelombang air dangkal adalah gelombang yang terjadi pada air dangkal yang mana panjang gelombangnya cukup besar dibandingkan kedalamannya.

Pada tahun 2013, Flouri et al. [2], menjelaskan terkait diskritisasi persamaan gelombang air dangkal non linear 2D dengan memperhatikan topografi menggunakan skema tipe Godunov serta disimulasikan pada kasus tsunami Hazard. Roberts [3] mengkaji tentang solusi numerik dari hukum konservasi yang diaplikasikan pada persamaan gelombang air dangkal. Crowhurst [4] dan Saiduzzaman et al.[5] mengkaji tentang solusi numerik dari persamaan gelombang air dangkal satu dimensi menggunakan metode beda hingga. Pada tahun 2019, Setiyowati et al.[6] dalam tulisannya mengkaji tentang penurunan model persamaan gelombang air dangkal 2D dan 1D, serta melakukan simulasi menggunakan metode volume hingga skema Lax-Friedrichs.

Pada penelitian ini disajikan hasil kontruksikan ulang persamaan gelombang air dangkal 1D dari Robert [3] dan Setiyowati et al.[6]. Selanjutnya, ditentukan penyelesaian numerik persamaan gelombang air dangkal 1D menggunakan metode beda hingga skema Lax-Friedrichs. Selain itu, pada penelitian ini dilakukan simulasi numerik dengan tujuan untuk mengetahui hubungan antara nilai awal amplitudo gelombang dan fungsi topografi terhadap tinggi gelombang tsunami yang dihasilkan. Selain itu, dilakukan interpretasi dari hasil penerapan dan simulasi numerik gelombang air dangkal pada kasus gelombang pantai dengan topografi tidak datar.

\section{Metode Penelitian}

Dalam melakukan penelitian digunakan metode kajian pustaka. Kajian pustaka dilakukan dengan mengumpulkan bahan referensi berupa buku, dan jurnal mengenai persamaan gelombang air dangkal, konstruksi ulang model, simulasi, dan interpretasi. Pada tahap konstruksi ulang model diawali dengan penjelasan terkait persamaan gelombang air dangkal 2D menggunakan hukum konservasi massa dan hukum konservasi momentum. Selanjutnya, diasumsikan variabel $y$ diabaikan sehingga diperoleh persamaan gelombang air dangkal 1D. Selanjutnya, model tersebut diterapkan pada kasus tsunami selat sunda dan diselesikan secara numerik menggunakan metode beda hingga skema Lax-Friedrichs. Berikut diberikan uraian tentang persamaan 
gelombang air dangkal 2D, persamaan gelombang air dangkal 1D, dan algoritme beda hingga skema Lax-Friedrichs.

\subsection{Persamaan Gelombang Air Dangkal 2D}

Model persamaan gelombang air dangkal 2D mengasumsikan profil gelombang air sebagai masalah dua dimensi yakni sebagai fungsi dua variabel ruang yaitu $\mathrm{x}$ dan $\mathrm{y}$ dengan $\mathrm{t}$ adalah variabel waktu non-negatif yang mana proses penurunannya mengacu pada Robert [3] dan Setiyowati [6].

Setiyowati [6] memaparkan bahwa persamaan gelombang air dangkal berlaku untuk fluida homogen yang memiliki massa jenis konstan, bersifat inviscid (tidak kental), incompressible (tidak dapat dimampatkan), dan mengalir secara irrotational. Berikut notasi-notasi dasar yang digunakan pada persamaan gelombang air dangkal 2D yang dapat dilihat pada Gambar 1.

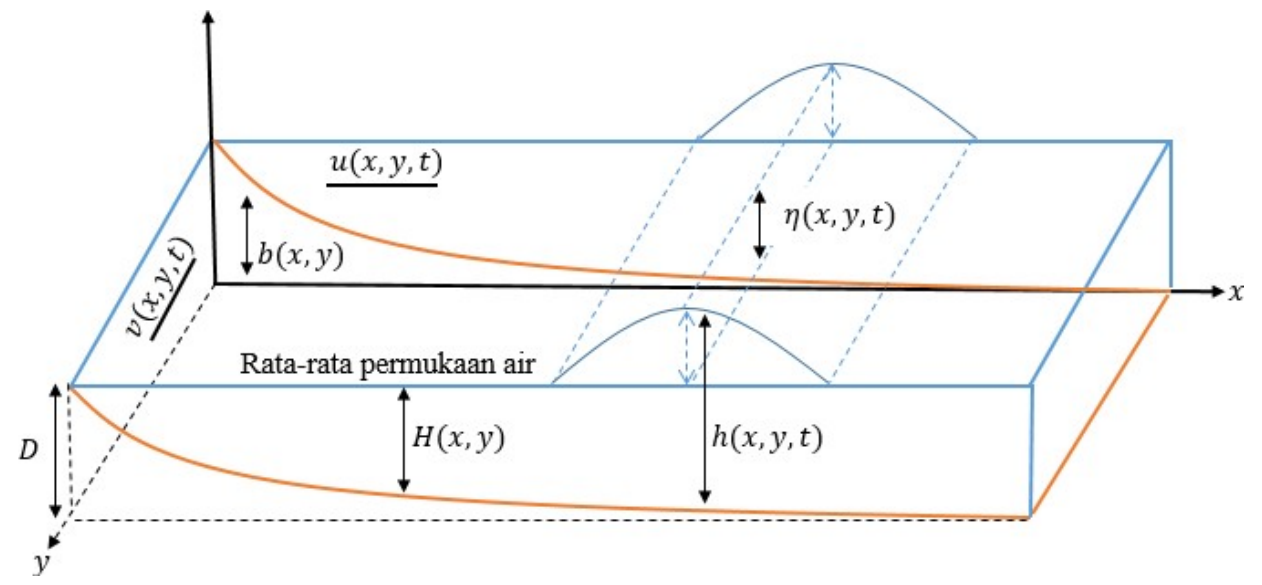

Gambar 1. Struktur dasar persamaan gelombang air dangkal 2D oleh Setiyowati[6]

Berdasarkan Gambar 1, D menyatakan ketinggian rata-rata permukaan air (diukur dari dasar topografi bawah) dan bernilai konstan, $b(x, y)$ menyatakan fungsi topografi bawah, $H(x, y)=D-b(x, y)$ menyatakan kedalaman air di bawah rata-rata permukaan air, $\eta(x, y, t)$ menyatakan fungsi perpindahan air di atas rata-rata permukaan air, $h(x, y, t)=H(x, y)+$ $\eta(x, y, t)$ menyatakan total kedalaman air, $u(x, y, t)$ menyatakan kecepatan pada arah $x$, dan $v(x, y, t)$ menyatakan kecepatan pada arah $y$. Persamaan gelombang air dangkal diturunkan dari hukum konservasi.

\section{Hukum Konservasi Massa}

Hukum konservasi massa adalah prinsip yang menyatakan bahwa laju perubahan massa fluida di suatu ruang pada selang waktu $t$ harus sama dengan perbedaan laju massa yang masuk dan laju massa yang keluar. 
Dimisalkan $\rho$ menyatakan massa jenis suatu fluida, diambil permukaan fluida yaitu $\left(\left[x_{0}, x_{1}\right],\left[y_{0}, y_{1}\right]\right)$ dan didefinisikan suatu massa fluida merupakan perkalian antara massa jenis fluida $\rho$ dan ketinggian fluida $h(x, y, t)$, sehingga diperoleh total massa pada permukaan fluida $\left(\left[x_{0}, x_{1}\right],\left[y_{0}, y_{1}\right]\right)$ pada waktu ke $t$ yaitu

$$
m_{\text {total }}=\int_{x_{0}}^{x_{1}} \int_{y_{0}}^{y_{1}} \rho h(x, y, t) d y d x .
$$

Total massa fluida berubah sesuai dengan aliran masuk dan aliran keluar fluida. Laju aliran massa fluida adalah massa fluida dikalikan dengan kecepatan rata-rata fluida $u$ untuk variabel $x$ dan $v$ untuk variabel $y$. Menggunakan teorema fundamental kalkulus, perubahan total massa fluida yang berlaku untuk cell yang dipilih dalam ruang dan waktu dan massa jenis $\rho$ bernilai konstan adalah

$$
h_{t}+(h u)_{x}+(h v)_{y}=0 .
$$

Persamaan (1) merupakan hukum konservasi massa dari persamaan gelombang air dangkal 2D.

\section{Hukum Konservasi Momentum}

Hukum Newton II menyatakan bahwa perubahan momentum terhadap waktu dari suatu sistem sama dengan total gaya yang bekerja pada fluida. Gaya yang diperhatikan disini adalah gaya tekanan.

Didefinisikan total momentum pada permukaan $\Omega_{t}$ yaitu

$$
\int_{\Omega_{t}} \mathbf{p} \mathrm{d} \mathbf{x}
$$

dengan $\Omega_{t}=\left\{(x, y, t) \in \mathbb{R} \mid x_{0} \leq x \leq x_{1}, y_{0} \leq y \leq y_{1}, t_{0} \leq t \leq t_{1}\right\}, \mathbf{p}=\mathbf{u} h$, dan $\mathbf{x}=(x, y)$. Hukum Newton II dapat ditulis secara matematis sebagai berikut

$$
F=\frac{d \mathbf{p}}{d t}
$$

dengan $F$ menyatakan gaya (Newton) dan p menyatakan momentum (kg.m/s). Diasumsikan bahwa tekanan fluida dalam domain $\Omega$ meningkat secara linear terhadap kedalaman fluida (tekanan hidrostatis), dan tekanan pada permukaan bebas fluida adalah konstan sehingga diperoleh

$$
\mathbf{p}_{t}+\nabla \cdot(\mathbf{p} \otimes \mathbf{u})+\nabla\left(\frac{1}{2} g h^{2}\right)=-g h \nabla b
$$

dengan $\mathbf{p} \otimes \mathbf{u}$ adalah tensor product dan $g h \nabla b$ adalah gaya pada topografi bawah. Persamaan (2) merupakan persamaan dari hukum konservasi momentum. Oleh karena, $\mathbf{p}=\mathbf{u} h$ dengan $\mathbf{u}=$ 
$(\boldsymbol{u}, \boldsymbol{v})$ dan $\mathbf{x}=(x, y)$, maka Persamaan (2) dapat diuraikan menjadi sistem dari dua persamaan diferensial yaitu

$$
\begin{aligned}
& (h u)_{t}+\left(h u^{2}+\frac{1}{2} g h^{2}\right)_{x}+(h u v)_{y}=0 \\
& (h v)_{t}+(h u v)_{x}+\left(h v^{2}+\frac{1}{2} g h^{2}\right)_{y}=0 .
\end{aligned}
$$

Berdasarkan pembahasan di atas, diperoleh persamaan gelombang air dangkal 2D dari Persamaan (1) dan (3), atau dapat dituliskan dalam bentuk

$$
\begin{gathered}
h_{t}+(h u)_{x}+(h v)_{y}=0 \\
(h u)_{t}+\left(h u^{2}+\frac{1}{2} g h^{2}\right)_{x}+(h u v)_{y}=-g h b_{x} \\
(h v)_{t}+(h u v)_{x}+\left(h v^{2}+\frac{1}{2} g h^{2}\right)_{y}=-g h b_{y} .
\end{gathered}
$$

\subsection{Persamaan Gelombang Air Dangkal 1D}

Persamaan gelombang air dangkal 1D hanya bergantung pada variabel ruang $x$ dan variabel waktu $t$ yang berarti notasi untuk fungsi topografi, perpindahan air di atas permukaan air, dan total kedalaman air masing-masing adalah $b(x), \eta(x, t)$, dan $h(x, t)$. Total kedalaman air pada posisi $x$ dan pada waktu ke $t$ dinyatakan dalam persamaan berikut

$$
h(x, t)=D-b(x)+\eta(x, t)
$$

Persamaan gelombang air dangkal 1D sama dengan persamaan gelombang air dangkal 2D namun ditambah asumsi bahwa komponen arah $y$ diabaikan, sehingga diperoleh model persamaan gelombang air dangkal satu dimensi (1D) sebagai berikut

$$
\begin{aligned}
h_{t}+(h u)_{x} & =0 \\
(h u)_{t}+\left(h u^{2}+\frac{1}{2} g h^{2}\right)_{x} & =-g h b_{x}
\end{aligned}
$$

Dengan mensubstitusikan $h=\eta+D-b$ ke Persamaan (4) diperoleh Persamaan (5) yaitu

$$
\begin{aligned}
\eta_{t}+(u(\eta+D-b))_{x} & =0 \\
u_{t}+\left(\frac{1}{2} u^{2}+g \eta\right)_{x} & =0 .
\end{aligned}
$$




\subsection{Algoritme Beda Hingga Skema Lax-Friedrichs}

Dimisalkan $x \in\left[x_{\min }, x_{\max }\right]$ dan $t \in[0, T]$. Pada metode beda hingga, diskritisasi grid untuk variabel $x$ dibagi $N$ interval dengan jarak yang sama sehingga terdapat $N+1$ titik dengan $x=i \Delta x, \Delta x=\frac{x_{\max }}{N}$, dan $i=0,1, \ldots, N$. Kemudian untuk variabel $t$ dibagi menjadi $M$ interval sehingga terdapat $M+1$ titik dengan $t=j \Delta t, \Delta t=\frac{T}{M}$, dan $j=0,1, \ldots, M$. Nilai $\Delta t$ juga dapat ditentukan menggunakan formula

$$
\Delta t=\frac{\lambda \Delta x}{\max \left(c_{1}, c_{2}\right)}
$$

dengan $\lambda$ merupakan nilai Courant dan

$$
c_{1,2}=u_{0} \pm \sqrt{g h_{0}}, \quad h_{0}=D+A
$$

dengan $g=9.81 \mathrm{~m} / \mathrm{s}^{2}$, serta $u_{0}$ merupakan kecepatan awal gelombang pada saat $t=0$.

Skema Lax-Friedrichs merupakan bentuk pengembangan dari skema eksplisit sehingga untuk menyelesaikan persamaan diferensial parsial digunakan pendekatan beda maju untuk turunan terhadap variabel waktu $t$, dan pendekatan beda pusat untuk turunan terhadap variabel ruang $x$. Pembagian partisi digunakan untuk memudahkan perhitungan secara numerik pada skema LaxFriedrichs dapat dilihat pada Gambar 2.

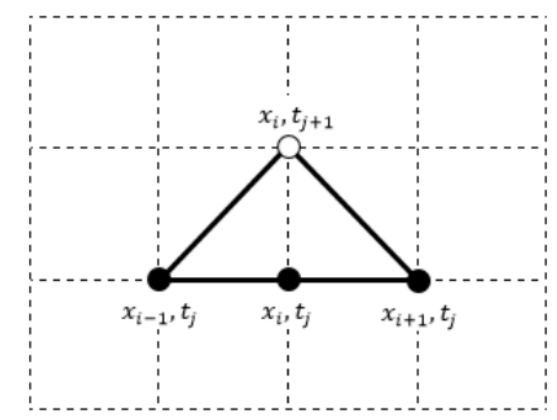

Gambar 2. Skema Lax-Friedrichs

Dasar dari skema Lax-Friedrichs adalah nilai dari $(i, j)$ pada skema eksplisit diganti dengan ratarata dari $(i+1, j)$ dan $(i-1, j)$ sehingga diperoleh bentuk diskrit dari $\eta(x, t), u(x, t)$, dan $b(x)$ adalah

$$
\begin{gathered}
\eta_{i}^{j}=\frac{\eta_{i+1}^{j}+\eta_{i-1}^{j}}{2}, u_{i}^{j}=\frac{u_{i+1}^{j}+u_{i-1}^{j}}{2}, \\
b_{i}=\frac{b_{i+1}+b_{i-1}}{2}
\end{gathered}
$$


Pada persamaan gelombang air dangkal 1D (6) terdapat lima turunan yaitu turunan pertama dari $\eta$ dan $u$ terhadap $t$ serta turunan pertama dari $\eta, u$, dan $b$ terhadap $x$. Menggunakan pendekatan beda maju untuk turunan terhadap variabel waktu $t$ dan pendekatan beda pusat untuk turunan terhadap variabel ruang $x$, diperoleh

$$
\begin{gathered}
\eta_{t}=\frac{\eta_{i}^{j+1}-\eta_{i}^{j}}{\Delta t}, u_{t}=\frac{u_{i}^{j+1}-u_{i}^{j}}{\Delta t}, \\
\eta_{x}=\frac{\eta_{i+1}^{j}-\eta_{i-1}^{j}}{2 \Delta x}, u_{x}=\frac{u_{i+1}^{j}-u_{i-1}^{j}}{2 \Delta x}, \\
b_{x}=\frac{b_{i+1}-b_{i-1}}{2 \Delta x} .
\end{gathered}
$$

Persamaan (6) dan (7) disubstitusikan ke dalam Sistem Persamaan (5) sehingga diperoleh penyelesaian numerik persamaan gelombang air dangkal 1D menggunakan metode beda hingga skema Lax-Friedrichs

$$
\begin{aligned}
& \eta_{i}^{j+1}=\left(\frac{\eta_{i+1}^{j}+\eta_{i-1}^{j}}{2}\right)-\frac{\Delta t}{2 \Delta x}\left(\left(\eta_{i+1}^{j}+D-b_{i+1}\right) u_{i+1}^{j}-\left(\eta_{i-1}^{j}+D-b_{i-1}\right) u_{i-1}^{j}\right) \\
& u_{i}^{j+1}=\left(\frac{u_{i+1}^{j}+u_{i-1}^{j}}{2}\right)-\frac{g \Delta t}{2 \Delta x}\left(\eta_{i+1}^{j}-\eta_{i-1}^{j}\right)-\frac{\Delta t}{2 \Delta x}\left(\frac{\left(u_{i+1}^{j}\right)^{2}+\left(u_{i+1}^{j}\right)^{2}}{2}\right) .
\end{aligned}
$$

\section{Hasil dan Pembahasan}

Pada penelitian ini dilakukan simulasi numerik persamaan gelombang air dangkal 1D pada persamaan (5) terhadap kasus tsunami berdasarkan amplitudo gelombang dan memisalkan fungsi topografi dasar laut $b(x)$ yang mendekati bentuk topografi Selat Sunda pada penelitian Giachetti et al.[7]. Selain itu nilai amplitudo gelombang awal juga diambil dari Giachetti et al.[7]. Tujuan dari simulasi ini dilakukan untuk mengetahui hubungan antara nilai awal amplitudo gelombang dan fungsi topografi terhadap tinggi gelombang tsunami yang dihasilkan.

Diambil $x \in[0,100000]$ dengan garis pantai Banten terletak pada $x=50000$ meter, dan posisi longsoran gunung Anak Krakatau terletak pada $x=100000$ meter. Topografi pada Giachetti et al. [7] diambil untuk fungsi topografi pada jarak 9 kilometer dari posisi longsoran mengarah ke garis pantai, dan untuk fungsi topografi setelahnya dimisalkan berupa fungsi linear, sehingga diperoleh fungsi topografi dasar laut seperti pada Gambar 3. 


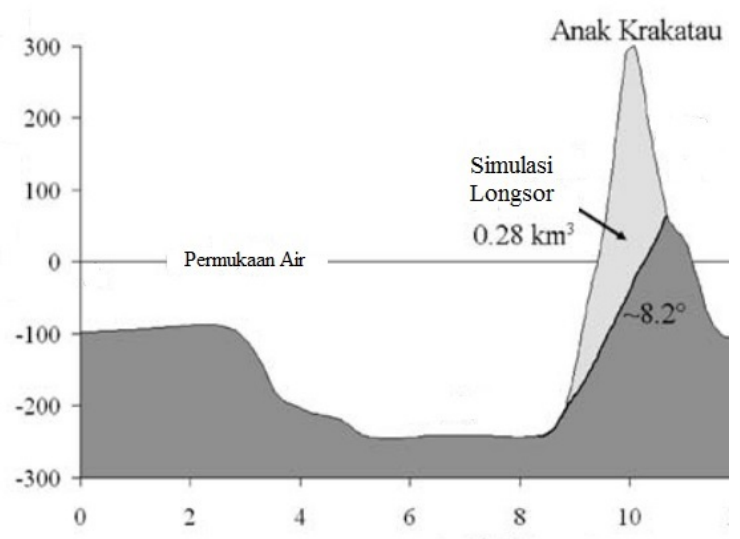

Gambar 3. Topografi dasar laut Selat Sunda oleh Giachetti et al. [7]

Berdasarkan Gambar 3, dikembangkan topografi dasar laut selat sunda didekati dengan empat fungsi topografi $b(x)$ yaitu

$$
\begin{aligned}
& b_{1}(x)=\left\{\begin{array}{lc}
\frac{-x}{200,}+600, & 0 \leq x \leq 50000 ; \\
0, & 7500000<x \leq 75000 ; \\
-\frac{(x-105000)^{2}}{400000}+200, & 100000<x \leq 105000 ; \\
200, & 105000<x \leq 110000 ;
\end{array}\right. \\
& b_{2}(x)=\left\{\begin{array}{lc}
200, & 0 \leq x \leq 50000 ; \\
\frac{-(x-50000)}{3125000}+200, & 50000<x \leq 75000 ; \\
-\frac{(x-105000)^{2}}{125000}+200, & 700000<x \leq 105000 ; \\
200, & 105000<x \leq 110000 ;
\end{array}\right. \\
& b_{3}(x)=\left\{\begin{array}{lc}
\begin{array}{l}
200, \\
\frac{-(x-75000)}{3125000},
\end{array} & 50000<x \leq 75000 ; \\
0, & 75000<x \leq 100000 ; \\
-\frac{(x-105000)^{2}}{125000}+200, & 100000<x \leq 105000 ; \\
200, & 105000<x \leq 110000 ;
\end{array}\right.
\end{aligned}
$$




$$
b_{4}(x)=\left\{\begin{array}{lr}
200, & 0 \leq x \leq 50000 \\
\frac{-x}{100}+700, & 50000<x \leq 60000 \\
100, & 60000<x \leq 700000 \\
-\frac{(x-70000)^{2}}{250000}+200, & 70000<x \leq 75000 \\
0, & 75000<x \leq 100000 \\
-\frac{(x-105000)^{2}}{125000}+200, & 105000<x \leq 11000 \\
200, & 105000<x \leq 11000
\end{array}\right.
$$

dengan fungsi topografi $b_{1}(x)$ merupakan fungsi topografi yang berbentuk sloping bed, $b_{2}(x)$ merupakan topografi landai, $b_{3}(x)$ merupakan topografi curam, dan $b_{4}(x)$ merupakan fungsi topografi modifikasi antara $b_{1}(x)$ dan $b_{2}(x)$ namun lebih curam dibandingkan fungsi topografi $b_{2}(x)$ dan lebih landai dibandingkan $b_{1}(x)$. Berikut diberikan sketsa fungsi topografi dasar laut seperti pada Gambar 4.

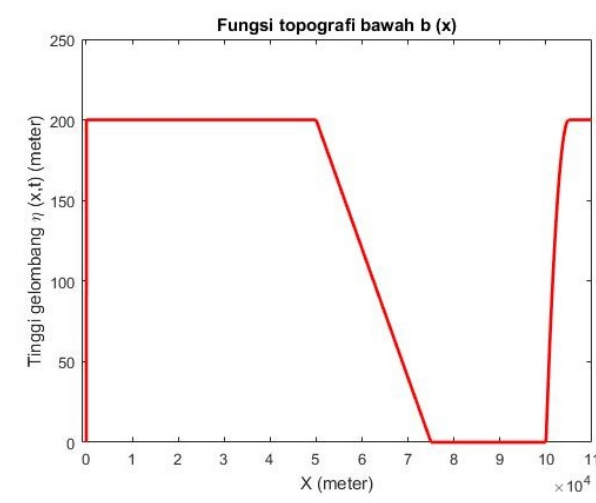

(a) $b_{1}(x)$

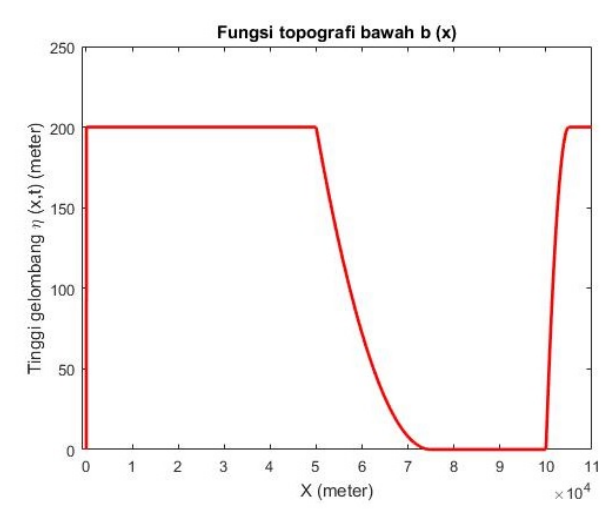

(c) $b_{3}(x)$

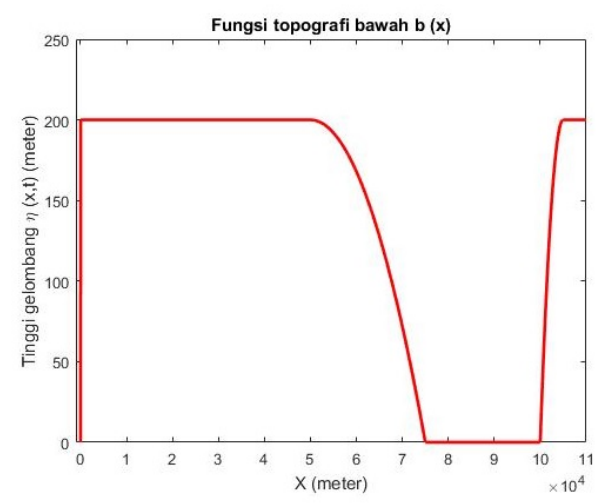

(b) $b_{2}(x)$

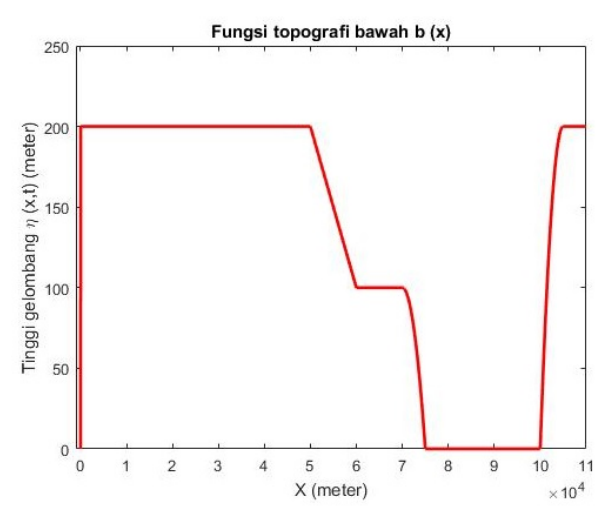

(d) $b_{4}(x)$

Gambar 4. Fungsi topografi dasar laut $b(x)$

Kemudian, diberikan syarat awal gelombang yang berupa gelombang soliter dan kecepatan gelombang pada $t=0$ yang diambil dari Setiyowati et al.(2019), yaitu 


$$
\eta(x, 0)=A \operatorname{sech}\left(\sqrt{\frac{3}{4 D^{2}}}(x-97500)\right)
$$

dan $u(x, 0)=0$. Selanjutnya, diambil beberapa nilai awal amplitudo gelombang A yaitu 15,20 , 25, dan 30 meter dengan posisi gelombang awal terletak pada $x=97500$ meter. diambil amplitudo gelombang awal $A$ dari Giachetti et al. [7] yaitu 45 meter dengan posisi gelombang awal terletak pada $x=97500$ meter.

Selanjutnya, simulasi numerik dilakukan pada domain variabel ruang $x \in[0,100000]$ dan variabel waktu $t \in[0,1000]$. Diskritisasi dilakukan pada grid terstruktur dengan partisi ruang adalah cell $\Delta x=\frac{100000}{N}$ dan partisi waktu $\Delta t$ diperoleh dari kriteria CFL. Diambil banyaknya grid $N$ adalah 2000, dan nilai Courant $\lambda$ dari Setiyowati et al.[6] adalah 0.68 sehingga diperoleh

$$
\Delta x=50, \Delta t=\frac{(0.68) \Delta x}{\max \left(c_{1}, c_{2}\right)}
$$

dengan $c_{1,2}=u_{0} \pm \sqrt{g h_{0}}, h_{0}=D+A, g=9.81 \mathrm{~m} / \mathrm{s}^{2}$, dan $u_{0}=0 \mathrm{~m} / \mathrm{s}$

Hasil simulasi numerik dievaluasi pada posisi garis pantai $(x=50000$ meter $)$ dengan nilai awal amplitudo gelombang $A$ yaitu 15, 20, 25, dan 30 meter, fungsi topografi $b_{1}(x), b_{2}(x), b_{3}(x)$ dan $b_{4}(x)$, syarat awal $(10)$, dan $u(x, 0)=0$ terhadap waktu tempuh $(t)$ dan maksimum tinggi gelombang $(\max (\eta(x, t)))$ dapat dilihat pada Tabel 1 .

Tabel 1. Hasil simulasi berdasarkan $A$ dan $b(x)$ terhadap waktu tempuh dan tinggi gelombang

\begin{tabular}{|c|c|c|c|c|c|c|c|c|}
\hline \multirow{2}{*}{$A$} & \multicolumn{2}{|c|}{$b_{1}(x)$} & \multicolumn{2}{|c|}{$b_{2}(x)$} & \multicolumn{2}{|c|}{$b_{3}(x)$} & \multicolumn{2}{|c|}{$b_{4}(x)$} \\
\cline { 2 - 9 } & $t$ & $\max (\eta(x, t))$ & $t$ & $\max (\eta(x, t))$ & $t$ & $\max (\eta(x, t))$ & $t$ & $\max (\eta(x, t))$ \\
\hline 15 & 859.52 & 2.4359 & 889.14 & 2.1331 & 835.83 & 2.7416 & 866.93 & 2.3834 \\
\hline 20 & 857.02 & 3.1487 & 886.29 & 2.7724 & 833.59 & 3.5238 & 865.07 & 3.0839 \\
\hline 25 & 855.40 & 3.8225 & 884.35 & 3.3822 & 831.52 & 4.2554 & 862.64 & 3.7474 \\
\hline 30 & 853.21 & 4.4612 & 882.56 & 3.9643 & 829.59 & 4.9437 & 860.37 & 4.3766 \\
\hline
\end{tabular}

Berdasarkan Tabel 1 dapat dilihat bahwa untuk fungsi topografi $b_{3}(x)$ dihasilkan tinggi gelombang yang paling besar dengan kisaran antara 2.7 sampai 4.9 meter, sedangkan untuk kasus fungsi topografi $b_{2}(x)$ dihasilkan tinggi gelombang yang paling kecil dengan kisaran antara 2.1 sampai 3.9 meter. Selain itu untuk fungsi topografi $b_{1}(x)$ dan $b_{4}(x)$ menghasilkan tinggi gelombang dengan kisaran 2.4 sampai 4.4 meter. Hal tersebut berlaku untuk semua nilai 
amplitudo gelombang awal yang diberikan. Tabel 1 menunjukkan juga bahwa fungsi topografi yang menghasilkan gelombang dengan waktu tempuh tersingkat untuk sampai kedaratan adalah fungsi topografi $b_{3}(x)$, dan yang terlama adalah fungsi topografi $b_{2}(x)$. Dengan demikian, dapat disimpulkan bahwa semakin landai topografinya, maka tinggi gelombang yang dihasilkan semakin kecil dan waktu tempuh yang dibutuhkan gelombang untuk sampai ke daratan semakin lama.

Selanjutnya, simulasi numerik dievaluasi pada waktu $t=1000$ detik dengan tujuan untuk melihat seberapa jauh gelombang masuk ke daratan sehingga diperoleh hasil seperti pada Tabel 2.

Tabel 2. Hasil simulasi terhadap posisi dan tinggi gelombang maksimum pada waktu $t=1000$ detik

\begin{tabular}{|c|c|c|c|c|c|c|c|c|}
\hline \multirow{2}{*}{$A$} & \multicolumn{2}{|c|}{$b_{1}(x)$} & \multicolumn{2}{c|}{$b_{2}(x)$} & \multicolumn{2}{c|}{$b_{3}(x)$} & \multicolumn{2}{c|}{$b_{4}(x)$} \\
\cline { 2 - 9 } & $x$ & $\max (\eta(x, t))$ & $x$ & $\max (\eta(x, t))$ & $x$ & $\max (\eta(x, t))$ & $x$ & $\max (\eta(x, t))$ \\
\hline 15 & 44350 & 2.0294 & 45150 & 1.8980 & 42750 & 2.1279 & 44150 & 2.0145 \\
\hline 20 & 43750 & 2.6310 & 45050 & 2.4677 & 42650 & 2.7513 & 44050 & 2.6120 \\
\hline 25 & 43600 & 3.1983 & 44900 & 3.0076 & 42550 & 3.3375 & 43950 & 3.1772 \\
\hline 30 & 43500 & 4.7393 & 44860 & 3.5257 & 42450 & 3.8951 & 43850 & 3.7163 \\
\hline
\end{tabular}

Berdasarkan hasil pada Tabel 2 dapat dilihat bahwa semakin besar amplitudo gelombang awal maka semakin besar tinggi gelombang yang dihasilkan dan semakin jauh gelombang masuk ke daratan. Pada fungsi topografi $b_{1}(x)$ dapat dilihat bahwa dengan amplitudo awal 30 meter gelombang mencapai posisi terjauh yaitu 43500 meter atau 6.5 kilometer dari garis pantai dengan ketinggian gelombang maksimum adalah 3.7393 meter. Pada fungsi topografi $b_{2}(x)$ dengan amplitudo awal 30 meter gelombang mencapai posisi terjauh yaitu 44850 meter atau 5.15 kilometer dari garis pantai dengan ketinggian gelombang maksimum adalah 3.5257 meter. Pada fungsi topografi $b_{3}(x)$ dengan amplitudo awal 30 meter gelombang mencapai posisi terjauh yaitu 42450 meter atau 7.55 kilometer dari garis pantai dengan ketinggian gelombang maksimum adalah 3.8951 meter. Dan pada fungsi topografi $b_{4}(x)$ dengan amplitudo awal 30 meter gelombang mencapai posisi terjauh yaitu 43850 meter atau 6.15 kilometer dari garis pantai dengan ketinggian gelombang maksimum adalah 3.7163 meter..

Hasil pada Tabel 2 menunjukkan juga bahwa topografi $b_{3}(x)$ yang merupakan topografi curam menghasilkan tinggi gelombang yang paling besar dan jarak tempuh yang paling jauh dibandingkan tiga topografi lainnya, sehingga dapat disimpulkan bahwa semakin besar amplitudo 
gelombang awal yang diberikan dan semakin curam topografi dasar lautnya maka semakin besar tinggi gelombang yang dihasilkan dan semakin jauh jangkauan gelombang yang masuk ke daratan.

\section{Simpulan}

Berdasarkan hasil dan pembahasan diperoleh model persamaan gelombang air dangkal 1D dengan topografi tidak flat dan algoritme beda hingga skema Lax-Friedrichs dari persamaan gelombang air dangkal 1D. Pada penelitian ini persamaan gelombang air dangkal dibatasi pada dimensi satu dengan fungsi topografi yang sederhana. Metode numerik yang digunakan untuk mencari penyelesaian persamaan gelombang air dangkal 1D adalah metode beda hingga skema Lax-Friedrichs. Simulasi numerik dilakukan dengan tujuan untuk mengetahui hubungan antara nilai awal amplitudo gelombang dan fungsi topografi terhadap tinggi gelombang tsunami yang dihasilkan. Berdasarkan hasil simulasi dapat disimpulkan bahwa semakin besar amplitudo gelombang yang diberikan maka tinggi gelombang yang dihasilkan semakin besar, waktu yang dibutuhkan gelombang untuk sampai ke daratan semakin singkat, dan jangkauan gelombang masuk ke daratan semakin jauh. Semakin curam fungsi topografi yang diberikan maka semakin besar tinggi gelombang yang dihasilkan, waktu yang dibutuhkan gelombang untuk sampai ke daratan semakin singkat, dan jangkauan gelombang masuk ke daratan semakin jauh. Pada penelitian selanjutnya dapat dikembangkan persamaan gelombang air dangkal dua dimensi atau lebih, serta diselesaikan secara numerik menggunakan skema yang lain seperti skema CrankNicolson. Selain itu, dapat juga dikembangkan untuk fungsi topografi yang lebih bervariasi atau yang mendekati bentuk topografi pada kasus nyata.

\section{Daftar Pustaka}

[1] C. E. Synolakis, "The runup of solitary waves," J. Fluid Mech., vol. 185, no. May, pp. 523-545, 1987, doi: 10.1017/S002211208700329X.

[2] E. T. Flouri, N. Kalligeris, G. Alexandrakis, N. A. Kampanis, and C. E. Synolakis, "Application of a finite difference computational model to the simulation of earthquake generated tsunamis," Appl. Numer. Math., vol. 67, pp. 111-125, 2013, doi: 10.1016/j.apnum.2011.06.003.

[3] S. G. Roberts, "Numerical solution of conservation laws applied to the Shallow Water Wave Equations," vol. 2013, p. 199, 2013. 
[4] P. Crowhurst and Z. Li, "Numerical solutions of one-dimensional shallow water equations," Proc. - UKSim 15th Int. Conf. Comput. Model. Simulation, UKSim 2013, no. April, pp. 55-60, 2013, doi: 10.1109/UKSim.2013.63.

[5] M. Saiduzzaman and S. K. Ray, "Comparison of Numerical Schemes for Shallow Water Equation," Glob. J. Sci. Front. Res. Math. Decis. Sci., vol. 13, no. 4, 2013.

[6] R. Setiyowati and Sumardi, "A Simulation of Shallow Water Wave Equation Using Finite Volume Method: Lax-Friedrichs Scheme,” J. Phys. Conf. Ser., vol. 1306, no. 1, 2019, doi: $10.1088 / 1742-6596 / 1306 / 1 / 012022$.

[7] T. Giachetti, R. Paris, K. Kelfoun, and B. Ontowirjo, "Tsunami hazard related to a flank collapse of Anak Krakatau Volcano, Sunda Strait, Indonesia," Geol. Soc. Spec. Publ., vol. 361, no. 1, pp. 79-90, 2012, doi: 10.1144/SP361.7. 